\title{
English as a Foreign Language Learners' Major and Meta-cognitive Reading Strategy Use at Al-Balqa Applied University
}

\author{
Tamador Khalaf Abu-Snoubar ${ }^{1}$ \\ ${ }^{1}$ Department of English Language and Literature, Al- Salt Faculty for Humanities, Al- Balqa Applied University, \\ Jordan \\ Correspondence: Tamador Khalaf Abu-Snoubar, Department of English Language and Literature, Al- Salt \\ Faculty for Humanities/ Al- Balqa Applied University, Jordan. E-mail: tamadorenglish@bau.edu.jo
}

Received: July 3, 2017 Accepted: August 3, 2017 Online Published: August 6, 2017

doi: 10.5539/elt.v10n9p69 URL: http://doi.org/10.5539/elt.v10n9p69

\begin{abstract}
This quantitative study aimed to investigate and compare the use of metacognitive reading Strategies among English as a foreign language students at Al-Balqa Applied University based on their academic field of study. The Survey of Reading Strategies (SORS) (Mokhtari \& Sheory, 2002) was the instrument employed. This survey divides the strategies into three categories: global, problem solving and support strategies. The 86 participants are enrolled in different academic fields of study and were classified into two groups: students of the faculties of humanities $(39=45.3 \%)$ and scientific faculties students $(47=54.7 \%)$. The participants proved to be high users of the overall strategies $(\mathrm{M}=3.6023$, S.D. $=1.3189)$ and they employed the strategies in the following order: problem solving, support and global. No statistically significant changes were found between the two groups concerning at the significance level of 0.05 . The most employed strategy by the humanities students was the support strategy "I go back and forth in the text to find relationships among ideas in it" $(\mathrm{M}=4.5385$, S.D. $=.83661)$. The scientific faculties students top ranked strategy was problem solving "I read slowly and carefully to make sure I understand what I am reading" $(\mathrm{M}=4.2128$, S.D. $=0.8831)$. The finding obtained would help EFL curricula planners and teachers to deepen their understanding of the learners' reading procedures.
\end{abstract}

Keywords: EFL, reading strategy, metacognitive, major, faculties of humanities, scientific faculties

\section{Introduction}

Although it is a confirmed truth that reading comprehension is essential for academic success and career progress, Jordanian students can be rated as unskilled readers. Their suffering usually waxes when they join university and face the large quantity of reading materials to be handled in English. In spite of the true faithful efforts undertaken by The Ministry of Education to turn out proficient readers, a deep understanding of how Jordanian learners approach a reading text remains the focal point that can wisely guide these efforts.

The way English as a Foreign Language learners use the metacognitive reading strategies has occupied a large space in the corpus of contemporary educational research. Many studies simply investigated the learners' awareness of these strategies (Marteniz, 2008; Singhal, 2001; Akkararitutthikun \& Sappappan, 2013; Lien, 2014; Shikano, 2013) while a good number tried to investigate the existence of any relations between the employment of these strategies and other variables. For example, Jom'a (2013), Alsheikh and Mokhtari (2011), Mirzapour and Mozaheb (2015) and Hoang (2016) explored the relation between using the reading strategies and the learners' proficiency level.

The effect of utilizing metacognitive reading strategies on reading comprehension was given attention by Tavakoli (2014), Suharni (2017) and Rastegar, Kermani and Khabir (2017). A good number of papers tackled the how gender differences affected the use of metacognitive reading strategies like Mahasneh, Alkhawaldeh and Almakanin (2016), Sheory and Mokhtari (2012), Chen and Chen (2015), Kocaman and Beskardesler (2016). Some studies dealt with the metacognitive strategies employed while reading on-line texts like Genc (2008), Zarrabi (2015) and Darwish (2017). The effectiveness of subjecting the EFL learners to metacognitive reading strategies training program was dealt with in Sebias (2013) and Alkhawaldeh (2015). Studies comparing how differently students majoring in different fields of study employ the metacognitive reading strategies is a field that still needs more in-depth investigation, however. 
Springing from a disbelief in a distorted image adapted by most EFL researchers stereotyping the scientific faculties students as more skilled readers than students of humanities (Dalili \& Tavakoli, 2013), this study aims at comparing the metacognitive awareness of the students enrolled in the scientific faculties and those majoring in the fields of humanities.

\subsection{Statement of the Problem}

In spite of the remarkable quantity of research papers investigating the metacognitive reading strategies and how they affect the proficiency and reading comprehension, differences due to learners' majors is a route scarcely trodden by researchers worldwide as well as in the Arab world. The noticeable lack in our knowledge as EFL teachers, instructors and curricula planners in Jordan encouraged the researcher to investigate how differently EFL students at the faculties of humanities and the scientific faculties at Al-Balqa Applied University utilize the metacognitive reading strategies.

\subsection{Theoretical Framework}

Reading strategies are techniques that both native and non-native students employ to enhance their comprehension and overcome difficulties they face when reading passages in English (Lee, 2012). Utilizing these reading strategies also allows the students the chance to properly understand the texts they read. (Monsakorn, 2012). Researchers like Magogwe (2013) and Lein (2014) divide the reading strategies into two categories. The first category constitutes the cognitive reading strategies which support the learners with the skills that enable them to infer the meaning from the text they tackle. The second category is spared for the metacognitive strategies which are defined as the strategies that give the readers the abilities and arrangements needed to assess their reading process. The metacognitive strategies are divided into three subcategories: global, support and problem solving.

Studies highlighting the existence of a relation between the use of these metacognitive strategies and the major of the EFL learners still need to be conducted to give more value and intensity to the body of knowledge proposed so far.

\subsection{Purpose of the Study}

There are many studies investigating the factors that affect EFL students' use of metacognitive reading strategies, but little in-depth knowledge is available about the differences on the favorite reading strategy use due to students' academic fields of study at university level. This study aimed at examining how differently EFL students studying at the faculties of humanities and the scientific faculties employ reading comprehension metacognitive strategies.

\subsection{Research Questions}

The aim of the current study is to explore the metacognitive reading strategies employed by EFL students of Humanities and Scientific Faculties at Al-Balqa Applied University. The proposed research questions are

1) How frequently do EFL students of humanities and scientific Faculties at Al-Balqa Applied University use the metacognitive reading strategies?

2) Is there a significant difference in the frequency of metacognitive reading strategy use between EFL students of the faculties of humanities and the scientific faculties students at Al-Balqa Applied University?

3) Which metacognitive reading strategies are employed most by EFL humanities students at Al-Balqa Applied University?

4) Which metacognitive reading strategies are employed most by EFL scientific faculties students at Al- Balqa Applied University?

\subsection{Significance of the Study}

The current study gets its significance from the fact that it highlights the differences concerning the use of the metacognitive reading strategies due to the different academic fields of study of Jordanian EFL students at Al-Balqa Applied University.

Although research in the field of reading strategies has become the center of attention since they help us gain more information about how learners sort out their problems while dealing with a written text, up to the researcher's knowledge, this study is one of the few attempts that examine this field in the region. Therefore, this study is meant to be a contribution in the effort to bridge this gap since reading comprehension is the most needed skill for any learners' educational and career opportunities in EFL countries.

Findings of this study his should be allowed to find their way to the practical levels of education to motivate 
school teachers and curricula planners to improve their awareness of these strategies and approaches.

\subsection{Definition of Terms}

For reasons of clarity, providing definitions of the important terms used in this study depending on Mokhtari and Sheory (2002) is thought to be important

English as a foreign language or EFL refers to societies where English is studied by non-native speakers and is not used as medium of daily communication.

Reading strategies are the methods the readers utilize in order to increase their comprehension and overcome any possible problems confronting them when reading English passages.

Metacognitive strategies are the techniques which learners carefully employ to assess or manage their reading process.

Support strategies are the group of techniques that help the reader to comprehend the text during reading. Examples of these strategies are when learners choose to underline key words, highlight important points and pay attention to the typographical aspects of the text. Support strategies also cover the areas of using reference materials from the text such as notes in the margins, summarizing, or simple underlining of important information.

Global Reading Strategies refer to the techniques through which learners arrange their process of reading and comprehension. The pre-reading activities as using existing knowledge and setting a goal before reading are examples of these strategies.

Problem-Solving Strategies constitute techniques that readers resort to so that they can overcome difficulties facing them while reading an English text. "Rereading hard to understand text" and "adapting one's reading rate to the difficulty level of what they're reading" are examples of these strategies.

\subsection{Limitations of the Study}

The current study is limited to EFL students at the center faculties of Al-Balqa Applied University, during the spring semester of the academic year 2016-2017.

\section{Literature Review}

A good bulk of studies probing the area of metacognitive reading strategies dealt with students' use and awareness of these strategies in general or tried to trace the existence of a remarkable relation between second language proficiency and the use of reading strategies, while a limited number of studies have tried to turn the spotlight on how a student's field of study may affect his employment of certain reading strategies.

\subsection{EFL Learners' Awareness and Use of the Metacognitive Reading Strategies}

Mahasneh, Alkhawaldeh and Almakanin (2016) examined how EFL Jordanian students employ the metacognitive reading strategies. The sample consisted of 148 participants who completed the Metacognitive Awareness of Reading Strategies Inventory (MARSI). The results and findings obtained demonstrated that the participants were high users of the overall strategies. It was found that the students preferred problem solving strategies most while the support strategies were the least favored.

The use of the metacognitive reading strategies by university students was the topic of a study by Tavakoli (2014). The participants completed the Survey of Reading Strategies (SORS) and were interviewed and set for a reading comprehension test. The findings demonstrated that the participants were moderate users of the metacognitive reading strategies and that the support strategies were the most used, followed by global strategies and problem solving, successively.

Mogogwe (2013) conducted his study to investigate how frequently university students in Botswana employ the metacognitive reading strategies. The analysis of the data obtained through the SORS instrument proved that the participants were high users of the overall strategies. Problem solving strategies were the most used, global strategies were used moderately and support strategies were the least employed.

The metacognitive reading strategies were found to be moderately to highly employed by the participants in Martinez (2008). The students of the faculty of Chemistry at the University of Ovido reported using problem solving strategies then global strategies, placing the support strategies as the least used.

\subsection{The Relation Between Metacognitive Reading Strategy Use and EFL Learners' Proficiency}

The Vietnamese students pursuing their education in England proved by Hoang (2016) to be medium users of the metacognitive reading strategies. The high proficiency students employed global strategies most, while the low 
proficiency learners opted for support strategies most often.

Mirzapour and Mozaheb (2015) conducted a study to explore the use of metacognitive reading strategies among university students with different proficiency levels. The data collection instruments employed were the Preliminary English Test (PET) and the Survey of Reading Strategies The findings demonstrated that the global strategies were more relied on by the students with high proficiency. The support strategies were employed equally by the two groups, however.

Akkararitwutthikun and Sappan (2013) explored how the Thai postgraduate students utilize the metacognitive reading strategies depending on a sample that consisted of 85 participants. The sample members were divided to a 31-participant group of high proficiency students and a 27-participant group of low proficiency students. All of the participants employed the overall strategies equally reporting themselves as high users of these strategies. The high proficiency students employed the global strategies most while the low proficiency students employed the problem solving strategies most often.

The Survey of Reading Strategies was employed by Jom'a (2013) to investigate the metacognitive reading strategies employed by high proficiency and low proficiency Birzit University EFL students when dealing with English texts. The highly proficient participants employed the reading strategies more often than the low proficiency students.

\subsection{EFL Learners' Major and Metacognitive Reading Strategy Use}

The area of reading strategy use of college students learning English as a foreign language in Korea was investigated by Park (2010). This study aimed to identify the how the use of reading strategies was affected by the students' majors. (SORS) was the instrument employed for data collection. The 115 participant learners belonged to different fields of study like Education, English Literature, English Education, French, Law, Business and Science and Engineering. They were grouped into three categories: Business (25 students), Education/Social Science/Humanities (71 students) and Engineering and Science (19 students). The overall strategy use reported that the participants were high users of the reading strategies with global strategies being the most used $(\mathrm{M}=3.57)$, followed by support strategies $(\mathrm{M}=3.38)$ and leaving problem solving strategies for the last place $(\mathrm{M}=3.92)$. The Education/Social Science/Humanities were the most active users of the overall strategies (Glob. $M=3.67$, Sup. $M=3.42$, Prob. $M=3.99$ ), followed by the Business students (Glob. $M=3.47$, Sup. $\mathrm{M}=3.36$, Prob. $\mathrm{M}=3.83$ ). The Engineering/Science students were the least active users of these strategies (Glob. $\mathrm{M}=3.57$, Sup. $\mathrm{M}=3.25$, Prob. $\mathrm{M}=3.76$ ).

Tabtabaei and Assari (2011) in their study "Investigating Strategic Processes of L2 Reading Comprehension Among Collegiate Iranian ESP Learners Across Three Academic Fields of Study" probed the existence of any significant differences among law, medical and computer engineering students concerning how they employ the metacognitive reading strategies. The $90 \mathrm{EFL}$ respondents $(30$ medical students, 30 computer engineering students and 30 law students) completed the SORS questionnaire. The five highest and the five lowest individual reading strategies were identified in order to provide a clear image of the findings. The overall reading strategy use was also made available. The medical students reported a moderate use of the overall strategies $(\mathrm{M}=3.49)$, the computer engineering students also employed these strategies moderately $(\mathrm{M}=3.2)$ while the law students proved to be moderate to high users of the overall strategies $(M=4.33)$. The use of the individual strategies reported significant differences among the three majors and no significant differences were found concerning the overall reading strategy use.

Jafari and Shokrpour (2012) administered a study to explore the reading strategies employed by Iranian students when they deal with authentic expository texts in English. The 81 participants were second year university students studying occupational health and safety, environmental health and midwifery at Shiraz University of Medical Studies. The results of the study proved to be significant. Students majoring in environmental health $(\mathrm{M}=3.68)$ used the metacognitive reading strategies more often than those majoring in occupational health and safety $(\mathrm{M}=3.63)$ and midwifery $(\mathrm{M}=3.43)$.

Monsakorn (2012) conducted a study to investigate and compare the use of metacognitive reading strategies among EFL students at Bangkok University from three different angles: gender, field of study and English learning experience. The 380 participants were first year students from social science and science departments, registered in the EN111 compulsory course and completed a questionnaire developed by researchers at Bangkok University. The findings revealed that males and females reported no differences in their use of the reading strategies. Students belonging to the two fields of study proved to be high users of these strategies also reported no significant differences in the employment of any of the reading strategies. A striking difference was found between the group that has spent less than eight years and the group that spent 8-12 years studying English. The 
first group members employed the metacognitive reading strategies more often than the second group.

Dalili and Tavakoli (2013) tried to answer the question whether there are significant differences between humanities and engineering students in the way they employ reading strategies while reading ESP materials. The sample consisted of seventy lower to intermediate college students (35 humanities students and 35 engineering students). The participants completed the Metacognitive Awareness of Reading Strategies Inventory. The findings depicted that although the two groups were majoring in different academic fields, they were found to similarly employ the overall reading strategies while reading ESP material (engineering students: $M=3.39$, $\mathrm{SD}=.52$, students of humanities: $\mathrm{M}=3.16, \mathrm{SD}=.50$ ). The students of humanities opted for global strategy number eight "using context clues" most while support strategy number four "discussing reading with others" was the least strategy used. Concerning the students of engineering, the highest strategy used was global strategy number eight "using context clues" while support strategy number eight "going back and forth in text" was the least preferred.

Shikano (2013) collected data through The Survey of Reading Strategies (SORS) to investigate the relations between the reading strategy use and reader's gender, academic major and reading proficiency. The 130 Japanese university students (69 social studies and 61 engineering majors) reported being upper-moderate users of the overall strategies (problem solving: $\mathrm{M}=3,45$; global strategies: $\mathrm{M}=3.38$ and support strategies: $\mathrm{M}=3.10$ ) and no significant differences were found due to gender. The other inter-group comparison based on major also highlighted the lack of any significant differences between the two groups (problem solving: social students $\mathrm{M}=3.54$ and engineering students $\mathrm{M}=3.38$; global strategies: social studies students $\mathrm{M}=3.39$ and engineering $\mathrm{M}=3.38$; support strategies: social studies $\mathrm{M}=3.16$ and engineering students $\mathrm{M}=3.03$ ). The third level of comparison based on proficiency reported significant differences. Proficient students employed the overall strategies more than the less proficient ones. They also reported highly employing the support strategies compared to the less proficient readers employed problem solving strategies more frequently.

Panchu, Bahuleyan and Seethalakshmi (2016) studied the metacognitive awareness of reading strategies among medical students who are supposed to be skilled readers. Metacognitive Awareness of Reading Strategies Inventory (MARSI) was the data collection instrument utilized in this study. The findings revealed that the metacognitive awareness of reading strategies was high. The strategies most preferred were the Problem solving strategies. The students second favorite strategies were the support strategies followed by global reading strategies.

\section{Methodology}

\subsection{Participants}

The study sample consisted of $86 \mathrm{EFL}$ freshmen to senior students (37 males and 49 females) enrolled in the English 101 and English 102 compulsory service courses. The participants have different proficiency levels, range from freshmen to seniors and belonged to two fields of studies: faculties of humanities an scientific faculties. Those registered in the faculties of humanities (39 respondents $=45.3 \%$ ) are majoring in Child Education, Arabic language and Literature, English Language and Literature, Law, Business, Business, Accounting and Project Planning, while those registered in the scientific faculties (47 respondents $=54.7 \%$ ) are majoring in Computer Science, Information Technology, Agriculture, Mathematics, Physics, Chemistry, Engineering, Medical Analysis and Medicine. It is worth mentioning that the participants belong to different social and economic backgrounds. Their ages range between 18 and 22.The sample of the study was selected through random sampling, and was determined based on (Sekaran, 2013).

\subsection{Instrument}

The Survey of Reading Strategies (SORS) by Mokhtari and Sheory (2002) is the instrument employed in this study. This 30 -item questionnaire consists is categorized into three subscales: problem solving strategies (represented by 8 items), support strategies (represented by 9 items) and global strategies (represented by 13 items). Since the language used in this questionnaire is clear and simple, there was no need for it to be translated into Arabic. The Cronbach's Alpha was applied to guarantee the instrument reliability which mounted to (88.8) as a whole. For more clarity, the global reading strategies' reliability was (85.33), the problem solving reading strategies reliability was (89.2), and the reliability of the support strategies was (77.7). The instructors administered the survey by asking the volunteers to complete the questionnaire in a process that took 15 minutes. Almost all the participants completed the survey. (Cronbach alpha) was applied to measure the stability of the measuring tool which proved to be excellent; being higher than the acceptable 60\%. (Miller, 2013). 


\subsection{Data Analysis and Characteristics of the Sample}

The Statistical Package for the Social Science (SPSS.Ver20) was used for analyzing the data and dealing with the study questions.

Characteristics of the study sample in terms of participants' major are illustrated in Table 1.

Table 1. Demographic characteristics of study sample (Major)

\begin{tabular}{lll}
\hline Major & Frequency & Percentage \\
\hline Scientific Faculties & 47 & $54.7 \%$ \\
Humanities & 39 & $45.3 \%$ \\
Total & 86 & $100.0 \%$ \\
\hline
\end{tabular}

Table 1 shows that $54.7 \%$ of respondents are (Scientific Faculties) and the rest are (Humanities), Figure 1 shows this percentage.
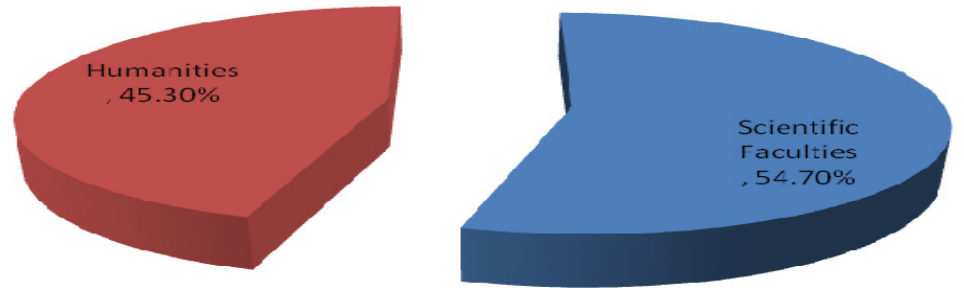

Figure 1. Demographic characteristics of study sample (Major)

\subsection{The Selection of the Sample of the Study}

A sample of (86) student was selected through random sampling, the sample of the study was determined based on Sekaran (2013).

\section{Results}

\section{Q1: How frequently do EFL students of Humanities and Scientific Faculties at Al-Balqa Applied University use the metacognitive reading strategies?}

In order to answer the first research question, descriptive statistics were used. The descriptive statistics included mean and standard deviations of each strategy use, the overall use, and the use of three strategy categories. The average score of the overall use of the EFL students at Balqa Applied University of metacognitive reading strategies was high $(\mathrm{M}=3.6023$, S.D. $=1.3189)$. According to Oxford and Burry- Stock (1995), Learning strategy usage scores averaging (3.5-5.0) are called as high, (2.5-3.4) are designated moderate; and scores ranging from $(1.0-2.4)$ are often assigned as low.

Table 2. Means and standard deviation of the frequency of metacognitive reading strategy use among EFL students of Humanities and Scientific Faculties at Al-Balqa Applied University

\begin{tabular}{llllll}
\hline Category & Questions & Mean & S.D. & Level & N \\
\hline Global & 1-I have a purpose in mind when I read. & 3.6860 & 1.2296 & High & 86 \\
Support & $\begin{array}{l}\text { 2-I take notes while reading to help me understand what I } \\
\text { read. }\end{array}$ & 3.4070 & 1.2212 & Moderate & 86 \\
Global & $\begin{array}{l}\text { 3- I think about what I know to help me understand what I } \\
\text { read. }\end{array}$ & 3.6163 & 1.1290 & High & 86 \\
& & & & & \\
\hline
\end{tabular}




\begin{tabular}{|c|c|c|c|c|c|}
\hline Global & $\begin{array}{l}\text { 4- I take an overall view of the text to see what it is about } \\
\text { before reading it. }\end{array}$ & 3.4767 & 1.2149 & Moderate & 86 \\
\hline Support & $\begin{array}{l}\text { 5-When text becomes difficult, I read aloud to help me } \\
\text { understand what I read. }\end{array}$ & 3.2606 & 1.3536 & Moderate & 86 \\
\hline Global & $\begin{array}{l}\text { 6-I think about whether the content of the text fits my } \\
\text { reading purpose. }\end{array}$ & 3.6163 & 1.2757 & High & 86 \\
\hline $\begin{array}{l}\text { Problem } \\
\text { solving }\end{array}$ & $\begin{array}{l}\text { 7-I read slowly and carefully to make sure I understand } \\
\text { what I am reading. }\end{array}$ & 4.1977 & .9433 & High & 86 \\
\hline Global & $\begin{array}{l}\text { 8-I review the text first by noting its characteristics like } \\
\text { length and organization. }\end{array}$ & 3.2442 & 1.3279 & Moderate & 86 \\
\hline $\begin{array}{l}\text { Problem } \\
\text { solving }\end{array}$ & 9-I try to get back on track when I lose concentration. & 3.9651 & 1.0895 & High & 86 \\
\hline Support & $\begin{array}{l}10-\text { I underline or circle information in the text to help me } \\
\text { remember it. }\end{array}$ & 4.1047 & 1.0293 & High & 86 \\
\hline Support & $\begin{array}{l}11-\text { I adjust my reading speed according to what I am } \\
\text { reading. }\end{array}$ & 3.6512 & 1.0929 & High & 86 \\
\hline $\begin{array}{l}\text { Problem } \\
\text { solving }\end{array}$ & $\begin{array}{l}\text { 12-When reading, I decide what to read closely and what to } \\
\text { ignore. }\end{array}$ & 3.2093 & 1.1794 & Moderate & 86 \\
\hline Global & $\begin{array}{l}\text { 13-I use reference materials (e.g, dictionary) to help me } \\
\text { understand what I read. }\end{array}$ & 3.6047 & 1.2393 & High & 86 \\
\hline $\begin{array}{l}\text { Problem } \\
\text { solving }\end{array}$ & $\begin{array}{l}\text { 14-When text becomes difficult, I pay closer attention to } \\
\text { what I am reading. }\end{array}$ & 3.9767 & 1.0735 & High & 86 \\
\hline Global & $\begin{array}{l}15-\mathrm{I} \text { use tables, figures, and pictures in text to increase my } \\
\text { understanding }\end{array}$ & 3.1860 & 1.2416 & Moderate & 86 \\
\hline $\begin{array}{l}\text { Problem } \\
\text { solving }\end{array}$ & $\begin{array}{l}16-\text { I stop from time to time and think about what I am } \\
\text { reading. }\end{array}$ & 3.4535 & 1.1848 & Moderate & 86 \\
\hline Global & $\begin{array}{l}17-\text { I use context clues to help me better understand what I } \\
\text { am reading. }\end{array}$ & 3.7791 & 1.0561 & High & 86 \\
\hline Global & $\begin{array}{l}\text { 18-I paraphrase (restate ideas in my own words) to better } \\
\text { understand what read. }\end{array}$ & 3.6977 & 1.1279 & Moderate & 86 \\
\hline $\begin{array}{l}\text { Problem } \\
\text { solving }\end{array}$ & $\begin{array}{l}\text { 19-I try to picture or visualize information to help } \\
\text { remember what I read. }\end{array}$ & 3.7093 & 1.1153 & Moderate & 86 \\
\hline Global & $\begin{array}{l}\text { 20-I use typographical features like bold face and italics to } \\
\text { identify key information. }\end{array}$ & 3.6860 & 1.1195 & Moderate & 86 \\
\hline Global & $\begin{array}{l}21-\mathrm{I} \text { check my understanding when I come across new } \\
\text { information. }\end{array}$ & 3.5930 & 5.7423 & High & 86 \\
\hline Support & $\begin{array}{l}\text { 22-I go back and forth in the text to find relationship } \\
\text { among ideas in it. }\end{array}$ & 3.2907 & 1.3272 & Moderate & 86 \\
\hline Global & $\begin{array}{l}\text { 23-I check my understanding when I come across new } \\
\text { information. }\end{array}$ & 3.7209 & 1.0809 & High & 86 \\
\hline Global & $\begin{array}{l}24-\text { I try to guess what the content of the text is about when } \\
\text { read. }\end{array}$ & 3.5233 & 1.2530 & High & 86 \\
\hline $\begin{array}{l}\text { Problem } \\
\text { solving }\end{array}$ & $\begin{array}{l}\text { 25-When text becomes difficult, I re-read it to increase my } \\
\text { understanding. }\end{array}$ & 4.0349 & .9634 & High & 86 \\
\hline Global & $\begin{array}{l}\text { 26-I ask myself equations I like to have answered in the } \\
\text { text. }\end{array}$ & 3.4186 & 1.1320 & Moderate & 86 \\
\hline Global & $\begin{array}{l}\text { 27-I check to see if my guesses about the text are right or } \\
\text { wrong. }\end{array}$ & 3.3837 & 1.1598 & Moderate & 86 \\
\hline
\end{tabular}




\begin{tabular}{llllll}
\hline $\begin{array}{l}\text { Problem } \\
\text { solving }\end{array}$ & $\begin{array}{l}\text { 28-When I read, I guess the meaning of unknown words or } \\
\text { phrases. }\end{array}$ & 3.4767 & 1.0259 & Moderate & 86 \\
Support & $\begin{array}{l}\text { 29-When reading I translate from English into my native } \\
\text { language. }\end{array}$ & 3.5581 & 1.2797 & High & 86 \\
Support & $\begin{array}{l}\text { 30-When reading, I think about information in both English } \\
\text { and my mother tongue. }\end{array}$ & 3.5116 & 1.3612 & High & 86 \\
Total & & $\mathbf{3 . 6 0 2 3}$ & $\mathbf{1 . 3 1 8 9}$ & High & $\mathbf{8 6}$ \\
\hline
\end{tabular}

Table 2 illustrates that the mean average for the answers of the EFL respondents about the use of the overall support strategies was high $(\mathrm{M}=3.6023$, S.D. $=1.3189)$. The participants depicted positive attitudes towards the above items because their mean was greater than the mean of the scale (3), but in different percentage. The highest mean in this table is given to problem solving strategy number (7) "I read slowly and carefully to make sure I understand what I am reading" (M=4.1977, S.D.=0.9433). Support strategy number (5) "when text becomes difficult, I read aloud to help me understand what I read" proved to be the strategy which the respondents least preferred ( $\mathrm{M}=3.2606$, S.D. $=1.3536)$.

\section{Q2: Is there a significant difference in the frequency of metacognitive reading strategy use between EFL} students of the faculties of humanities and the scientific faculties students at Al-Balqa Applied University?

To answer this research questions, descriptive statistics was used, which included mean and standard deviations of each strategy use, the overall use, and the use of three strategy categories, test (Independent Samples T-Test) was also used to determine differences between students enrolled in the faculties of humanities and the scientific faculties.

In order to identify the answer to this question, a test was used to determine field of study differences (faculties of humanities and the scientific faculties).

Table 3. Independent Samples T-Test to identify if there is a significant difference in the frequency of metacognitive reading strategy use between EFL students of the faculties of humanities and the scientific faculties' students at Al-Balqa Applied University

\begin{tabular}{lllllll}
\hline \multirow{2}{*}{$\begin{array}{l}\text { Major } \\
\text { Section }\end{array}$} & \multicolumn{2}{l}{ Scientific Faculties $(\mathbf{N}=\mathbf{4 7})$} & \multicolumn{2}{l}{ Humanities $(\mathbf{N}=\mathbf{3 9})$} & \multirow{2}{*}{ T } & \multirow{2}{*}{ Sig } \\
\cline { 2 - 5 } & Mean & S.D & Mean & S.D & & \\
\hline Problem & 3.7482 & 0.4962 & 3.7436 & 0.5565 & 0.41 & 0.645 \\
Support & 3.4601 & 0.6757 & 3.6763 & 0.5529 & 1.602 & 0.168 \\
Global & 3.5805 & 0.4714 & 3.3883 & 0.6060 & 1.655 & 0.087 \\
\hline
\end{tabular}

Table 3 shows that there are no significant statistical differences at $(\alpha \leq 0.05)$ level in the use of the reading metacognitive strategies among Al-Balqa Applied University students depending on the demographic variableMajor.

\section{Q3: Which metacognitive reading strategies are employed most by EFL humanities students at Al-Balqa Applied University?}

To identify the answer to this question, the arithmetic mean and the standard deviation of the three strategies (Global, Problem Solving, Support) were extracted. The highest strategy that is frequently used, and the arithmetic mean and the standard deviation of each paragraph can be presented as follows: 
Table 4. Metacognitive strategy use by EFL humanities students at Al-Balqa Applied University

\begin{tabular}{llll}
\hline Categories of strategies & Mean & Standard deviation (S.D) & Level \\
\hline The first Category: Problem solving & 3.7436 & 0.5565 & High \\
The Second Category: Support & 3.6763 & 0.5529 & High \\
Third Category: Global & 3.3883 & 0.6060 & Medium \\
\hline
\end{tabular}

It is noted from the previous table that there are differences in the arithmetic mean with respect to the employment of the three subcategories.

For the students studying at the faculties of humanities, the most favored of the subcategories is Problem Solving $(\mathrm{M}=3.7436$, S.D. $=0.5565)$, followed by support strategies $(\mathrm{M}=3.6763$, S.D. $=0.5529)$, and then global strategies $(\mathrm{M}=3.3883$, S.D. $=0.6060)$. Statistical details illustrating the pattern of strategy use (in descending order) is made available in Table 5.

Table 5. Means and standard deviation of strategy use by the faculties of humanities students

\begin{tabular}{|c|c|c|c|}
\hline Category & Questions & Mean & $\begin{array}{l}\text { Std. } \\
\text { Deviation }\end{array}$ \\
\hline Support & $\begin{array}{l}\text { 22-I go back and forth in the text to find relationship among ideas in } \\
\text { it. }\end{array}$ & 4.5385 & .83661 \\
\hline $\begin{array}{l}\text { Problem } \\
\text { solving }\end{array}$ & $\begin{array}{l}\text { 7-I read slowly and carefully to make sure I understand what I am } \\
\text { reading. }\end{array}$ & 4.1795 & 1.0227 \\
\hline Support & $\begin{array}{l}\text { 10-I underline or circle information in the text to help me remember } \\
\text { it. }\end{array}$ & 4.1026 & 1.0462 \\
\hline $\begin{array}{l}\text { Problem } \\
\text { solving }\end{array}$ & $\begin{array}{l}\text { 25-When text becomes difficult, I re-read it to increase my } \\
\text { understanding. }\end{array}$ & 4.0256 & .9864 \\
\hline $\begin{array}{l}\text { Problem } \\
\text { solving }\end{array}$ & $\begin{array}{l}\text { 14-When text becomes difficult, I pay closer attention to what I am } \\
\text { reading. }\end{array}$ & 4.0000 & 1.1002 \\
\hline $\begin{array}{l}\text { Problem } \\
\text { solving }\end{array}$ & 9-I try to get back on track when I lose concentration. & 3.9487 & 1.0500 \\
\hline Global & $\begin{array}{l}17-\text { I use context clues to help me better understand what I am } \\
\text { reading. }\end{array}$ & 3.8718 & .9228 \\
\hline Global & 3- I think about what I know to help me understand what I read. & 3.8205 & 1.0481 \\
\hline Global & $\begin{array}{l}\text { 18-I paraphrase (restate ideas in my own words) to better understand } \\
\text { what read. }\end{array}$ & 3.7949 & 1.0306 \\
\hline Global & 23-I check my understanding when I come across new information. & 3.7692 & 1.2452 \\
\hline Support & 2-I take notes while reading to help me understand what I read. & 3.7692 & .9857 \\
\hline Global & $\begin{array}{l}\text { 13-I use reference materials (e.g, dictionary) to help me understand } \\
\text { what I read. }\end{array}$ & 3.7179 & 1.1459 \\
\hline $\begin{array}{l}\text { Problem } \\
\text { solving }\end{array}$ & $\begin{array}{l}\text { 19-I try to picture or visualize information to help remember what I } \\
\text { read. }\end{array}$ & 3.7179 & 1.1459 \\
\hline $\begin{array}{l}\text { Problem } \\
\text { solving }\end{array}$ & 16-I stop from time to time and think about what I am reading. & 3.7179 & 1.2555 \\
\hline Support & 29-When reading I translate from English into my native language. & 3.6667 & 1.3245 \\
\hline Global & $\begin{array}{l}\text { 20-I use typographical features like bold face and italics to identify } \\
\text { key information. }\end{array}$ & 3.6410 & 1.2028 \\
\hline Support & $\begin{array}{l}\text { 30-When reading, I think about information in both English and my } \\
\text { mother tongue. }\end{array}$ & 3.6410 & 1.3276 \\
\hline
\end{tabular}




\begin{tabular}{llll}
\hline Global & 1-I have a purpose in mind when I read. & 3.6154 & 1.2899 \\
Global & 27-I check to see if my guesses about the text are right or wrong. & 3.5641 & 1.2095 \\
Global & 26- I ask myself equations I like to have answered in the text. & 3.5128 & 1.0729 \\
Global & 24- I try to guess what the content of the text is about when read. & 3.4872 & 1.2112 \\
Support & 11-I adjust my reading speed according to what I am reading. & 3.4615 & .9959 \\
Support & 5-When text becomes difficult, I read aloud to help me understand & 3.4103 & 1.3122 \\
what I read. & & \\
$\begin{array}{l}\text { Problem } \\
\text { solving }\end{array}$ & 28-When I read, I guess the meaning of unknown words or phrases. & 3.3333 & 1.1082 \\
Global & 21- I check my understanding when I come across new information. & 3.3077 & 1.3602 \\
Global & $\begin{array}{l}\text { 6-I think about whether the content of the text fits my reading } \\
\text { purpose. }\end{array}$ & 3.2564 & 1.3902 \\
Problem & 12-When reading, I decide what to read closely and what to ignore. & 3.2308 & 1.2452 \\
solving & 8-I review the text first by noting its characteristics like length and & 3.0769 & 1.3838 \\
Global & $\begin{array}{l}\text { organization. } \\
\text { 15- I use tables, figures, and pictures in text to increase my }\end{array}$ & 3.0256 & 1.3667 \\
Global & $\begin{array}{l}\text { 4- I take an overall view of the text to see what it is about before } \\
\text { reading it. }\end{array}$ & 3.0000 & 1.2140 \\
Global & & $\mathbf{3 . 6 4 0 1}$ & $\mathbf{1 . 4 1 2 2}$ \\
\hline Total & &
\end{tabular}

Table 5 shows that the Faculties of Humanities students are high users of the overall metacognitive reading strategies $(\mathrm{M}=3.6401$, S.D.=1.4122). As Shown in this table, there were positive attitudes toward the above questions because their mean were greater than the mean of the scale (3), but in different percentage. The item which gained the highest mean in this strategy is the support strategy "I go back and forth in the text to find relationship among ideas in it" $(\mathrm{M}=4.5385$, S.D. $=0.83661)$.

Q4: Which metacognitive reading strategies are most used by EFL scientific faculties students at Al-Balqa Applied University?

In order to identify the answer to the question, the study extracted the arithmetic mean and the standard deviation of the three strategies (Global, Problem Solving, Support). The highest strategy used, the arithmetic mean and the standard deviation of each item are presented in Table 6.

Table 6. Metacognitive reading strategies most employed by EFL scientific faculties students at Al-Balqa Applied University

\begin{tabular}{llll}
\hline Categories of strategies & Mean & Standard deviation (S.D) & Level \\
\hline The first Category: Problem solving & 3.7482 & 0.4962 & High \\
The Second Category: Support & 3.4601 & 0.6757 & High \\
Third Category: Global & 3.5805 & 0.4714 & High \\
\hline
\end{tabular}

It is noted from the previous table that there are differences in the arithmetic mean with respect to strategy use.

It is clear that for the students of the faculties of humanities, the most favored category is Problem Solving $(\mathrm{M}=3.7482$, S.D. $=0.4962)$, followed by Support Strategies $(\mathrm{M}=3.4601$, S.D. $=0.6757)$, and then Global $(\mathrm{M}=3.5805$, S.D. $=0.4714)$. Statistical details illustrating the pattern of strategy use is made available in a descending order in Table 7. 
Table 7. Means and standard deviation of the scientific faculties students

\begin{tabular}{|c|c|c|c|}
\hline Category & Questions & M. & S.D. \\
\hline $\begin{array}{l}\text { Problem } \\
\text { solving }\end{array}$ & $\begin{array}{l}\text { 7-I read slowly and carefully to make sure I understand what I am } \\
\text { reading. }\end{array}$ & 4.2128 & 0.8831 \\
\hline Support & 10-I underline or circle information in the text to help me remember it. & 4.1064 & 1.0265 \\
\hline $\begin{array}{l}\text { Problem } \\
\text { solving }\end{array}$ & $\begin{array}{l}\text { 25-When text becomes difficult, I re-read it to increase my } \\
\text { understanding. }\end{array}$ & 4.0426 & 0.9546 \\
\hline $\begin{array}{l}\text { Problem } \\
\text { solving }\end{array}$ & 9-I try to get back on track when I lose concentration. & 3.9787 & 1.1323 \\
\hline $\begin{array}{l}\text { Problem } \\
\text { solving }\end{array}$ & $\begin{array}{l}\text { 14-when text becomes difficult, I pay closer attention to what I am } \\
\text { reading. }\end{array}$ & 3.9574 & 1.0623 \\
\hline Global & 6-I think about whether the content of the text fits my reading purpose. & 3.9149 & 1.1000 \\
\hline Global & $\begin{array}{l}\text { 4- I take an overall view of the text to see what it is about before reading } \\
\text { it. }\end{array}$ & 3.8723 & 1.0758 \\
\hline Support & 11-I adjust my reading speed according to what I am reading. & 3.8085 & 1.1542 \\
\hline Global & 1-I have a purpose in mind when I read. & 3.7447 & 1.1881 \\
\hline Global & $\begin{array}{l}\text { 20-I use typographical features like bold face and italics to identify key } \\
\text { information. }\end{array}$ & 3.7234 & 1.0571 \\
\hline $\begin{array}{l}\text { Problem } \\
\text { solving }\end{array}$ & 19-I try to picture or visualize information to help remember what I read. & 3.7021 & 1.1017 \\
\hline Global & 17-I use context clues to help me better understand what I am reading. & 3.7021 & 1.1594 \\
\hline Global & 23-I check my understanding when I come across new information. & 3.6809 & 0.9350 \\
\hline Global & $\begin{array}{l}\text { 18-I paraphrase (restate ideas in my own words) to better understand } \\
\text { what read. }\end{array}$ & 3.6170 & 1.2078 \\
\hline $\begin{array}{l}\text { Problem } \\
\text { solving }\end{array}$ & 28-When I read, I guess the meaning of unknown words or phrases. & 3.5957 & 0.9478 \\
\hline Global & 24-I try to guess what the content of the text is about when read. & 3.5532 & 1.2990 \\
\hline Global & $\begin{array}{l}\text { 13-I use reference materials (e.g, dictionary) to help me understand what } \\
\text { I read. }\end{array}$ & 3.5106 & 1.3167 \\
\hline Support & 29-When reading I translate from English into my native language. & 3.4681 & 1.2485 \\
\hline Global & 3- I think about what I know to help me understand what I read. & 3.4468 & 1.1760 \\
\hline Support & $\begin{array}{l}\text { 30-When reading, I think about information in both English and my } \\
\text { mother tongue }\end{array}$ & 3.4043 & 1.3935 \\
\hline Global & 26-I ask myself equations I like to have answered in the text. & 3.404 & 1.1846 \\
\hline Global & $\begin{array}{l}\text { I review the text first by noting its characteristics, like length and } \\
\text { organization. }\end{array}$ & 3.3830 & 1.2778 \\
\hline Global & $\begin{array}{l}\text { 15-I use tables, figures, and pictures in text to increase my } \\
\text { understanding. }\end{array}$ & 3.3191 & 1.1249 \\
\hline Support & 22-I go back and forth in the text to find relationship among ideas in it. & 3.2766 & 1.13138 \\
\hline Global & 27-I check to see if my guesses about the text are right or wrong. & 3.2340 & 1.1075 \\
\hline $\begin{array}{l}\text { Problem } \\
\text { solving }\end{array}$ & 16-I stop from time to time and think about what I am reading. & 3.2340 & 1.0877 \\
\hline $\begin{array}{l}\text { Problem } \\
\text { solving }\end{array}$ & 12-when reading, I decide what to read closely and what to ignore. & 3.1915 & 1.1352 \\
\hline Support & $\begin{array}{l}5 \text {-when text becomes difficult, I read aloud to help me understand what I } \\
\text { read. }\end{array}$ & 3.1915 & 1.3931 \\
\hline
\end{tabular}




\begin{tabular}{llll}
\hline Support & 2. I take notes while reading to help me understand what I read. & 3.1064 & 1.3226 \\
Global & 21-I check my understanding when I come across new information. & 2.8085 & 1.3128 \\
Total & & $\mathbf{3 . 5 7 3 0}$ & $\mathbf{1 . 1 4 9 8 9}$ \\
\hline
\end{tabular}

Table 7 shows that the mean average for the answers about the frequency of strategy use by the scientific faculties EFL students was high (M=3.5730, S.D.=1.14989). As Shown in the table above, there were positive attitudes toward the above items because their mean were greater than the mean of the scale (3), but in different percentage. The phrase which gained the highest mean in isstrategy number (7) "I read slowly and carefully to make sure I understand what I am reading" $(\mathrm{M}=4.2128$, S.D. $=0.8831)$.

\section{Discussion}

Thorough statistical analysis concerning the first study question "How frequently do EFL students of humanities and scientific faculties at Al-Balqa Applied University use the metacognitive reading strategies?" proved that they are high users of the overall strategies $(M=3.6023$, S.D.=1.3189). This outcome supports previous studies like Jom'a (2013), Chen and Chen (2015), Mahasneh, Alkhawaldeh and Almakanin (2016), Monsakorn (2012), Zarrabi (2015), Rastegar, Kirmani and Khabir (2017), Poole (2009), Magogwe (2013) and Lien (2014) Who regardless of the aims of their studies have found their participants to be high users of the overall metacognitive reading strategies. The results of the present study are not consistent with other studies like Tabtabaei and Assari (2011), Jafari and Shokrpour (2012), Shikano (2013), Lee (2012), Tavakoli (2014), Hoang (2016) who conducted studies for a variety of aims found their participants to be moderate users of the overall reading strategies.

Concerning the second question "Is there a significant difference in the frequency of metacognitive reading strategy use between EFL students of the faculties of humanities and the scientific faculties?", the statistical analysis proved the absence of any significant differences at $(\alpha \leq 0.05)$ between the two groups. This result supports previous studies by Dalili and Tavakoli (2013), Shikano (2013), Panchu, Bahuleyan and Seethalakshmi (2016), Shikano (2013) and Park (2010) whose participants regardless of their fields of study similarly employed the reading strategies. The participants in Tabtabaei and Assari (2011), Jafari and Shokrpour (2012) and Monsakorn (2012) displayed that they utilize the strategies differently due to their major.

As for the students of the faculties of humanities, the most used category is Problem Solving $(\mathrm{M}=3.7436$, S.D. $=0.5565)$, and then Support $(M=3.6763$, S.D. $=0.5529)$, and the least favored category is Global $(\mathrm{M}=3.3883$, $\mathrm{S} . \mathrm{D}=0.6060$ ). Shifting the spotlight to the students of the scientific faculties, the most employed strategies are Problem Solving $(M=3.7482$, S.D. $=0.4962)$, and then Support $(M=3.4601$, S.D. $=0.6757)$, and the least used strategy is Global $(M=3.5805$, S.D. $=0.4714)$. This problem solving, support and global pattern is consistent with Marteniz (2008), Jafari and Shokrpour (2012), Jom'a (2013), Magogwe (2013), Shikano (2013) and Mahasneh, Alkhawaldeh and Almakanin (2016). Studies that do not support these findings do also exist. Alsheikh and Mokhtari's (2011) and Tavakoli's (2014) participants favored the support reading strategies most. Akkarararitwutthikun and Sappan (2013) and Hoang (2016) and Kocaman and Beskadesler (2016), revealed that their participants were relying on global reading strategies most.

The Faculties of Humanities students are high users of the overall metacognitive reading strategies $(M=3.6401$, S.D. =1.4122). The item which is ranked as the highest is the support strategy "I go back and forth in the text to find relationship among ideas in it" $(\mathrm{M}=4.5385$, S.D. $=0.83661)$. An explanation of this choice may be due to the kind of exams that humanities students are used to. Most of the exams held in the departments of humanities are essay exams, where students are supposed to establish comparisons and contrasts between certain themes or concepts or express their opinions concerning a certain point. These kinds of exam question need the students to keep an eye on relations between ideas more than demonstrating on points as separate islands.

Among the five top listed strategies, as illustrated in Table 5, three are problem solving and two are support strategies: support strategy "I go back and forth in the text to find relationships among ideas in it" $(M=4.5385$, S.D. $=0.83661$ ), Problem solving "I read slowly and carefully to make sure I understand what I am reading" $(\mathrm{M}=4.1795$, S.D. $=1.0227)$, support strategy " I underline or circle information in the text to help me remember it" $(\mathrm{M}=4.1026$, S.D. $=1.0227)$, problem solving "When text becomes difficult, I re-red it to increase my understanding" $(\mathrm{M}=4.0256$, S.D.=.9864) and problem solving "When text becomes difficult, I pay closer attention to what I am reading" (M=4.000, S.D.=1.1002).

Relying on these two groups of strategies which students depend on their personal efforts to develop point out 
the lack of teachers' and lecturers' knowledge concerning the importance of the global metacognitive strategies. As defined earlier in this paper, global reading strategies are those purposeful, intently planned techniques by which learners are taught how to organize or manage their reading. It refers to pre-reading activities such as having a purpose in mind before reading, thinking about what one already knows about the material before reading, using context clues, paraphrasing, using the typographical feature, note-taking, using reference materials, using tables and figures, and taking an overview of the text before reading. If these techniques are implemented, the time needed to achieve better comprehension of the reading text can be minimized and more efficiently utilized. The least used strategy by the students of humanities is global strategy "I take an overall view of the text to see what it is about before reading it" $(\mathrm{M}=3,000$, S.D.=1.2140). This supports the above-mentioned point concerning the importance of training teachers and learners to employ the global strategies.

As for the participants from the scientific faculties, they proved to be high users of the overall strategies $(\mathrm{M}=3.5730$, S.D. $=1.14989)$. The item which they ranked as highest is strategy number (7) "I read slowly and carefully to make sure I understand what I am reading" $(\mathrm{M}=4.2128$, S.D. $=0.8831)$.

A closer look at the contents of table(7) shows that four of the five most preferred strategies by the scientific faculties students belong to the problem solving subgroup: "I read slowly and carefully to make sure I understand what I am reading" $(\mathrm{M}=4.2128$, S.D=0.8831), "When text becomes difficult, I re-read it to increase my understanding" $(M=4.0426$, S.D. $=0,9546)$, "I try to get back on track when I lose concentration" $(M=3.9787$, S.D. $=1.1323)$ and "When text becomes difficult, I pay closer attention to what I am reading" $(\mathrm{M}=3.9574$, S.D.=1.0623). Only the second- rated strategy belongs to the support strategies sub-groups: "I underline or circle information in the text to help me remember it" (M=4.1064, S.D.=1.0265).

The noticeable presence of problem solving strategies is a positive indicator since their use characterize skilled readers (Dalili \& Tavakoli, 2013). The absence of strategies like "When reading, I translate from English into my native language" ( $M=3.4681)$ from the top five list is also another positive indicator of skilled readers.

A finding that is worth attention is that the scientific faculties students do not highly opt for the global strategy "I use tables, figures, and pictures in text to increase my understanding" $(M=3.3191)$ although their academic textbooks heavily rely on figures and pictures. This illustrates that they should receive planned training on how to employ these visual aids which can shorten the time needed for comprehending any reading text and help memory retain the information for a longer time.

Another phenomenon that is worth attention is that EFL scientific faculties students do not efficiently employ the global strategy "I use reference materials (e.g, dictionary) to help me understand what I read" (M=3.5106).

Dictionary use and reaching reference materials has never been easier. Online dictionaries and encyclopedic sources which are at the learners' finger tips can save the time needed for the understanding of any text and should receive more training.

The least five used metacognitive strategies by scientific majors are a mixture of the three subcategories. The presence of the support strategy "I take notes while reading to help me understand what I read" $(\mathrm{M}=3.1064)$

in this list as almost the lowest ranked is an indicator of the students' inability to use their own language and writing skills.

\section{Recommendations}

The recommendations affiliated to this study can be divided into two streams: pedagogical recommendations and recommendations for future research.

The findings earned from this study highlight the need for training programs that raise teachers' and instructors' awareness of the importance of implementing the reading strategies in their classes. According to Zhang (2009), inserting these techniques in any EFL class can make any reading experience a source of pleasure even especially for the low-proficient students. In addition, most of these strategies can be developed into life-long skills that can be a valuable asset in any learner's life.

Future researchers interested in this field are advised to conduct studies that employ large samples of students of different fields of study comparing the employment of these strategies while dealing with texts in both English and the participants' native languages, and while reading literary texts and academic texts.

Future research need also to invest more efforts in the field of on-line reading strategies especially because most of what is being read these days is obtained from online sources.

Qualitative research can be employed more effectively in this field. Recall protocol interviews, students' reading logs and notes are thought to give a deeper understanding of what goes on during the reading process. 


\section{References}

Akkararitwutthikun, S., \& Sappappan, P. (2013). A Survey to Assess Students' Metacognitive Awareness of Reading Strategies Used by the Master of Arts Program in English for Careers, Thammasat University. The 2nd LITU International Graduate Conference.

Alkhawaldeh, A. (2015). The Effect of an EFL Reading Strategies-Based Instructional Programme on Reading Achievement and Awareness of Reading Strategies among Jordanian High School Students. Middle-East Journal of Scientific Research, 23(5).

Alsheikh, N., \& Mokhtari, K. (2011). An Examination of Metacognitive Reading Strategies Used by Native Speakers of Arabic When Reading in English. English Language Teaching, 4(2). https://doi.org/10.5539/elt.v4n2p151

Chen, K., \& Chen S. (2015). The Use of EFL Reading Strategies Among High School Students in Taiwan. The Reading Matrix: An International Online Journal, 15(2).

Genc, H. (2011). Paper and Screen: Reading Strategies Used by Low-Proficient EFL Learners. Sino-US English Teaching, 8(10).

Dalili, M., \& Tavakoli, M. (2013). A Comparative Analysis of Reading Strategies Across ESP Students of Humanities and Engineering. International Journal of Research Studies in Language Learning, 2(5).

Darwish, I. (2017). Meta Cognitive Strategy Use: Off or ON in Online Reading. International Conference on Literature, History, Humanities and Social Sciences (LHHSS-17). Jan.1-2, Dubai (UAE).

Hoang, N. (2016). The Relationship Between Reading Strategy use and Reading Proficiency of Vietnamese Students in the UK. M.A. Thesis. Northumbria University, Published by British Council ELT Master's Dissertation Awards.

Jafari, S., \& Shokrpour, N. (2012). The Reading Strategies Used by Iranian ESP Students tp Comprehend Authentic Expository Texts in English. International Journal of Applied Linguistics and English Literature, 1(4). https://doi.org/10.7575/ijalel.v.1n.4p.102

Jom'a, F. (2013). Investigating Berziet Students' Awareness of their Knowledge and use of Metacognitive Reading Strategies. M.A Thesis. College of Graduate Studies, Bierzrit University, Palestine.

Kocaman, O., \& Beeskardesler. (2016). Meta cognitive Awareness of Reading Strategy Use by English Language Teaching Students in Turkish Context: Sakaraya University Sample. Sakaraya University Journal of Education, 6(2).

Lee, M. (2012). A Study of the Selection of Reading Strategies among Genders by EFL College Students. International Educational Technology Conference, published by Elsevier. https://doi.org/10.1016/j.sbspro.2012.11.037

Lien, H. (2014). Reading Strategy Awareness of English Major Students. International Journal of Social, Behavioral, Economic, Business and Industrial Engineering, 8(8).

Magogwe, J. (2013). Metacognitive Awareness of Reading Strategies of University of Botswana English as a Second Language Students of Different Academic Reading Proficiencies. Reading and Writing, 4(1). https://doi.org/10.4102/rw.v4i1.29

Mahasneh, A., Alkhawaldeh, M., \& Almakanin, H. (2016). Assessing Students' Metacognitive Awareness Reading Strategies in Jordan. North American Journal of Psychology, 18(2).

Martinez, A. (2008). Analysis of ESP University Students' Reading Strategy Awareness. Iberica, 15.

Miller, D. (2013). Measurement by the Physical Educator, Why and Low, (3rd. ed.) Indianapolis, Indiana, WM. C. Brown Communication, INC.

Mirzapour, F., \& Mozaheb, M. (2015). Reading Strategy Use Among Iranian EFL Learners Across Different Proficiency Levels. European Scientific Journal, 11(35).

Mokhtari, K., \& Sheory, R. (2002). Measuring ESL Students' Awareness of Reading Strategies. Journal of Developmental Education, 25(3).

Monsakorn, N. (2012). Awareness of Reading Strategies among EFL Learners at Bagkok University. International Journal of Social, Behavioral, Educational, Business and Industrial Engineering, 6(5).

Oxford, R., \& Ehrman, M. (1995). Assessing the use of language learning strategies worldwide with EFL/ESL 
version of the Strategy Inventory for Language Learning (SILL). System, 23(1), 1-23. https://doi.org/10.1016/0346-251X(94)00047-A

Panchu, P. (2016). Evaluation of Metacognitive Awareness. Journal of Research in Medical and Dental Science, 4(3). https://doi.org/10.5455/jrmds.2016435

Poole, A. (2009). The Reading Strategies Used by Male and Female Colombian University Students. Profile Issues in Teachers' Professional Development. Profile. no. 11.

Rastegar, M., Kermani, E., \& Khabir, M. (2017). The Relationship Between Metacognitive Reading Strategies Use and Reading Comprehension Achievement of EFL Learners. Open Journal of Modern Linguistics, 7(1). https://doi.org/10.4236/ojml.2017.72006

Sebais, F. (2013). Raising Students' Awareness about Readig Strategies: A Case Study of ESP Students at the Faculty of Biology. M.A.Thesis. University of Constantine 1, Department of Letters and English Language.

Sekaran, U., \& Bougie, R. (2013). Research Methods For Business: A Skill-Building Approach (6th ed.) John Wiley \& Sons.

Sheory, R., \& Mokhtari, K. (2001). Differences in the Metacognitive Awareness of Reading Strategies Among Native and Non-native Readers. System, 29(4). https://doi.org/10.1016/S0346-251X(01)00039-2

Shikano, M. (2015). Second Language Readers' Gender, Major, and Reading Strategy Use. Academia, Literature and Language (98).

Shikano, M. (2013). A Quantitative Survey on Metacognitive Awareness of Reading Strategy Use in English by Japanese University Students. International Education Centre Journal., 14.

Singhal, M. (2001). Reading Proficiency, Reading Strategies, Metacognitive Awareness and L2 Readers. The Reading Matrix, 1(1).

Suharni, T. (2017). The Use of Metacognitive Reading Strategies by EFL Learners in Reading. Research in English and Education (READ), 2(1).

Tabatabaei, O., \& Assari, F. (2011). Investigating Strategic Processes of L2 Reading Comprehension Among Collegiate Iranian ESP Learners Across Three Academic Fields of Study. Canadian Social Science, 7(5).

Tavakoli, H. (2014). The Effectiveness of Metaognitive Strategy Awareness in Reading Comprehension: The Case of Iranian University EFL Students. The Reading Matrix, 14(2).

Zarrabi, S. (2015). Exploring Metacognitive Online Reading Strategies of Non-Native English Speaking Translation Students. Doctoral Dessertation, University of Sn Francisco.

Zhang, L., \& Wu, I. (2009). Chinese Senior High School EFL Students' Metacognitive Awareness and Reading-Strategy Use. Reading in Foreign Language, 21(1). 


\section{Appendix 1}

\section{Survey of Reading Strategies}

Major:

\begin{tabular}{|c|c|c|c|c|c|}
\hline Phrase & $\begin{array}{l}\text { I never or } \\
\text { almost never } \\
(1)\end{array}$ & $\begin{array}{l}\text { Only } \\
\text { occasionally } \\
(2)\end{array}$ & $\begin{array}{l}\text { I } \\
\text { sometimes } \\
\text { (3) }\end{array}$ & $\begin{array}{l}\text { I } \\
\text { usually } \\
(4)\end{array}$ & $\begin{array}{l}\text { Always or } \\
\text { almost } \\
\text { always (5) }\end{array}$ \\
\hline \multicolumn{6}{|l|}{$\begin{array}{l}\text { 1-I have a purpose in mind when I } \\
\text { read. }\end{array}$} \\
\hline \multicolumn{6}{|l|}{$\begin{array}{l}\text { 2-I take notes while reading to help } \\
\text { me understand what I read. }\end{array}$} \\
\hline \multicolumn{6}{|l|}{$\begin{array}{l}\text { 3- I think about what I know to help } \\
\text { me understand what I read. }\end{array}$} \\
\hline \multicolumn{6}{|l|}{$\begin{array}{l}\text { 4- I take an overall view of the text } \\
\text { to see what it is about before } \\
\text { reading it. }\end{array}$} \\
\hline \multicolumn{6}{|l|}{$\begin{array}{l}\text { 5-When text becomes difficult, I } \\
\text { read aloud to help me understand } \\
\text { what I read. }\end{array}$} \\
\hline \multicolumn{6}{|l|}{$\begin{array}{l}\text { 6-I think about whether the content } \\
\text { of the text fits my reading purpose. }\end{array}$} \\
\hline \multicolumn{6}{|l|}{$\begin{array}{l}\text { 7-I read slowly and carefully to } \\
\text { make sure I understand what I am } \\
\text { reading. }\end{array}$} \\
\hline \multicolumn{6}{|l|}{$\begin{array}{l}\text { 8-I review the text first by noting its } \\
\text { characteristics like length and } \\
\text { organization. }\end{array}$} \\
\hline \multicolumn{6}{|l|}{$\begin{array}{l}\text { 9-I try to get back on track when I } \\
\text { lose concentration. }\end{array}$} \\
\hline \multicolumn{6}{|l|}{$\begin{array}{l}\text { 10-I underline or circle information } \\
\text { in the text to help me remember it. }\end{array}$} \\
\hline \multicolumn{6}{|l|}{$\begin{array}{l}\text { 11-I adjust my reading speed } \\
\text { according to what I am reading. }\end{array}$} \\
\hline \multicolumn{6}{|l|}{$\begin{array}{l}\text { 12-When reading, I decide what to } \\
\text { read closely and what to ignore. }\end{array}$} \\
\hline \multicolumn{6}{|l|}{$\begin{array}{l}\text { 13-I use reference materials (e.g, } \\
\text { dictionary) to help me understand } \\
\text { what I read. }\end{array}$} \\
\hline \multicolumn{6}{|l|}{$\begin{array}{l}\text { 14-When text becomes difficult, I } \\
\text { pay closer attention to what I am } \\
\text { reading. }\end{array}$} \\
\hline \multicolumn{6}{|l|}{$\begin{array}{l}\text { 15-I use tables, figures, and pictures } \\
\text { in text to increase my } \\
\text { understanding. }\end{array}$} \\
\hline \multicolumn{6}{|l|}{$\begin{array}{l}\text { 16-I stop from time to time and } \\
\text { think about what I am reading. }\end{array}$} \\
\hline $\begin{array}{l}\text { 17-I use context clues to help me } \\
\text { better understand what I am reading. }\end{array}$ & & & & & \\
\hline
\end{tabular}




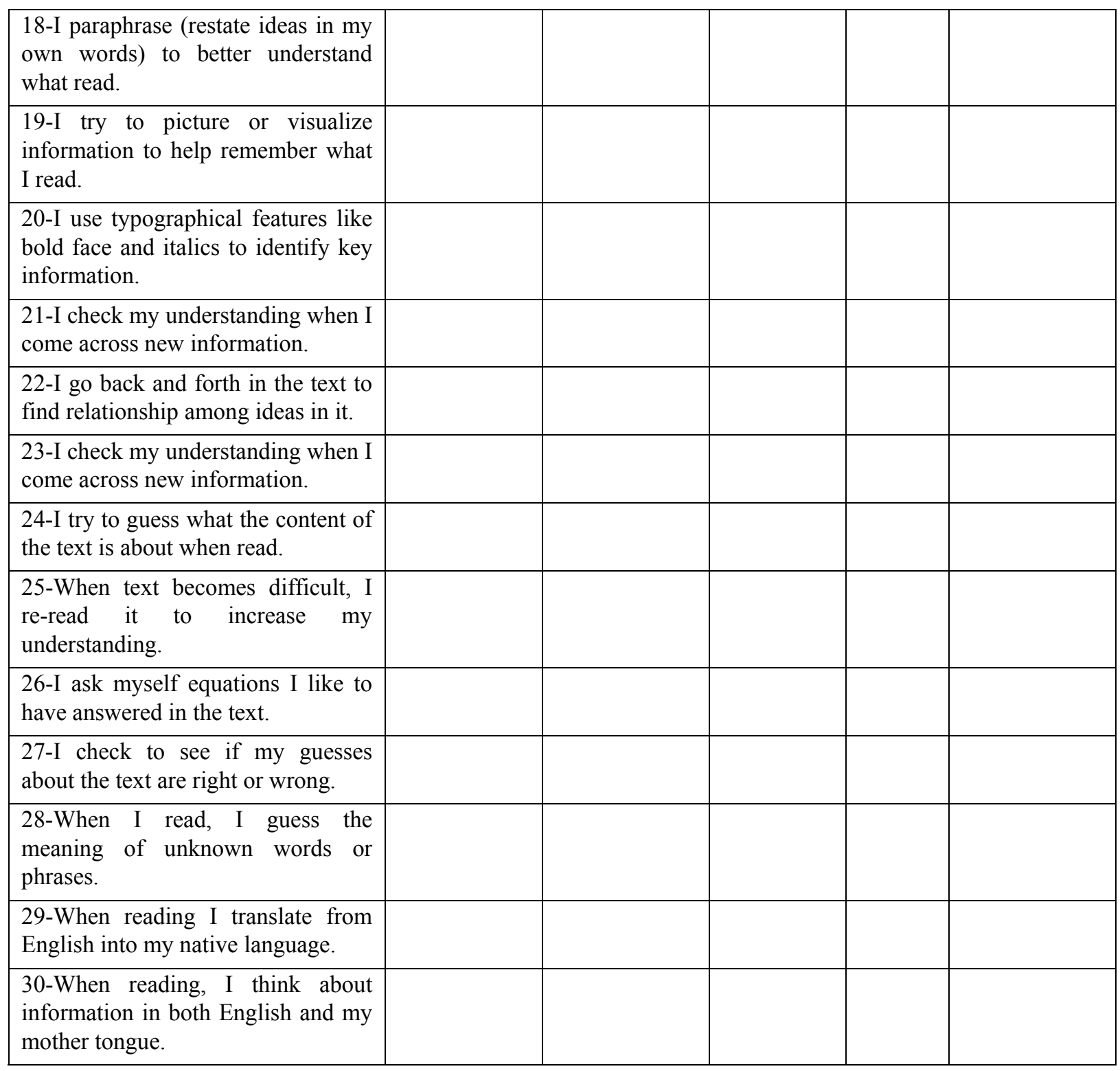

\section{Copyrights}

Copyright for this article is retained by the author(s), with first publication rights granted to the journal.

This is an open-access article distributed under the terms and conditions of the Creative Commons Attribution license (http://creativecommons.org/licenses/by/4.0/). 